\title{
Исследование спектров поглощения и отражения высокого разрешения в терагерцовом и дальнем инфракрасном диапазоне монокристаллов гибридных металлоорганических перовскитов
}

\author{
В.Е. Аникеева ${ }^{1,2}$, К.Н. Болдырев ${ }^{1,2}$, О.И. Семенова ${ }^{3}$, М.Н. Попова ${ }^{1}$ \\ ${ }^{1}$ Институт спектроскопии РАН, Троицк, Москва, 108840, Физическая, 5 \\ ${ }^{2}$ Национальный исследовательский университет «Высшая школа экономики», Москва, 101000, \\ Мясницикая, 20 \\ ${ }^{3}$ Институт физики полупроводников им. А.В. Ржанова СО РАН, Новосибирск, 630090, пр. ак. \\ Лаврентьева, 13 \\ тел:+7 (913) 392-7029, факс:+7 (495) 851-0886, эл.nочта: vanikeeva@hse.ru
}

DOI 10.34077/RCSP2021-91

Гибридные металлорганические перовскиты (МОП) относятся к классу полупроводниковых материалов, применяемых при создании оптоэлектронных устройств. В однокомпонентных солнечных элементах на основе МОП в апреле 2021 года была достигнута 25,6\% эффективность преобразования солнечной энергии в электрическую [1]. Рекордные показатели однокомпонентных солнечных элементов на основе МОП обусловлены такими свойствами как большая длина диффузии и высокая подвижность носителей заряда, а также широкая полоса поглощения в спектре солнечного излучения [2]. Исследование особенностей электрон-фононного взаимодействия позволяет прояснить природу и высокие значения многих характеристик гибридных перовскитов.

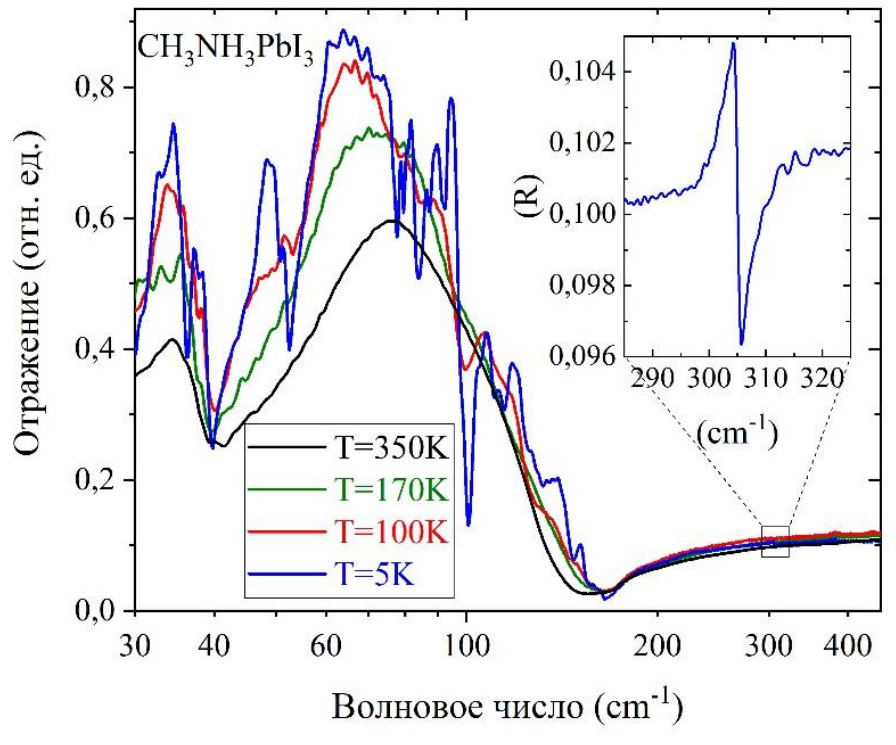

Рис. 1. Спектры отражения в частотном диапазоне от 30 до $400 \mathrm{~cm}^{-1}$ монокристалла $\mathrm{CH}_{3} \mathrm{NH}_{3} \mathrm{PbI}_{3}$ при четырёх температурах: $350 \mathrm{~K}$, $170 \mathrm{~K}, 100 \mathrm{~K}$ и $5 \mathrm{~K}$. На вставке справа представлена увеличенная часть спектра при $5 \mathrm{~K}$ с наблюдаемой впервые торсионной модой при $306 \mathrm{~cm}^{-1}$.

Работа выполнена при поддержке проекта РНФ (№ 19-72-10132) и Министерства науки и высшего образования РФ (ГЗ 0039-2019-0004 и 0306-2019-0015 - рост кристаллов, О.И.С.).

\section{Лumepamypa}

[1] J. Jeong, et al. // Nature. 2021. V.592. P.381-385.

[2] C. La-o-vorakiat, et. al. // J. Phys. Chem. Lett. 2016. V.7., 1. P.1-6.

[3] O. Semenova, et. al. // J. Cryst. Growth. 2017. V.462. P.45-49.

[4] K. Boldyrev, et. al. // J. Phys. Chem. C. 2020. V.124. P.23307-23316. 